\title{
Promoting academic achievement within a positive youth development framework
}

\author{
Marianne Beck and Nora Wiium \\ Faculty of Psychology, University of Bergen, Norway \\ nora.wiium@uib.no
}

\begin{abstract}
School dropout has both individual and economic implications. Current statistics reveal higher dropout rates among boys. Schools have a unique position to address youth development. Research from the US on positive youth development shows positive relationships between developmental assets (e.g. support at school) and academic achievement. The present paper examined these relationships among 591 Norwegian high school students (55\% girls), aged $15-19$ (mean $=16.70)$ with data from a cross-sectional study. Results indicated that girls reported more assets than boys did. Furthermore, while positive correlations occurred among assets and academic achievement, some assets (i.e. commitment to learning, support and positive identity) were better predictors of academic achievement in regression analysis. Schools can play a significant role in nurturing developmental assets that will promote academic achievement in both genders, as well as have implications for youth and consequently economic development.
\end{abstract}

This is an open access article distributed under the Creative Commons Attribution Licence, which permits unrestricted use, distribution, and reproduction in any medium, provided the original work is properly cited.

Adolescence is a period of biological, cognitive, psychological and social changes (Lerner, 2005). Along with such changes are increases in opportunities and responsibilities, where youth will have to make decisions that can have crucial consequences for their future. One important area of life is academic achievement. How youth perform in school can determine the possibilities they will have as adults. Schools are in a unique position to facilitate a successful transition to adulthood, and thus an important youth context. The Norwegian Education Act (1998) addresses the importance that schools have in child development, and states that: "The pupils and apprentices shall develop knowledge, skills and attitudes so that they can master their lives and can take part in working life and society" (§1.1). Lillejord et al. (2017) argued also that schools are responsible for developing realistic goals and expectations for pupils, as well as making sure that pupils have access to the developmental assets needed to reach such goals. In the present study, we address the role of developmental assets in youth contexts, such as the school, in academic achievement among high school students in Norway.

Despite school serving as a vital youth context, dropout rates in high schools are reported as one of the biggest problems in the Norwegian school system (Union of Education, 2017). Statistics show that 73\% of students in high school complete their education in five years (Statistics Norway, 2017), while a third drop out. Furthermore, statistics from the Norwegian Directorate for Children, Youth and Family Affairs (2017) suggest that there is a gender difference in high school completion, where $79 \%$ of girls complete in five years, while only $68 \%$ boys do the same.

Academic success has implications for the individual, but it also has societal and economic implications. Compared to persons who have graduated from high school, those who drop out generally have a lower quality of life: higher unemployment, more economic strain, lower income and higher use of welfare services (Union of Education, 2017). For every student that drop out of high school, Levin and Belfield (2007) estimated a societal lifetime cost of at least $\$ 240,000$. The negative outcomes of school dropout underline the importance of academic achievement for positive youth development and thriving later in life. Moreover, considering that stress and its associated negative effects on physical and psychological health are some of the possible reasons for high school dropout (Lillejord et al., 2017), positive youth development initiatives may protect against these and possibly reduce the societal cost that may be incurred.

\section{PoSITIVE YOUTH DEVELOPMENT AND DEVELOPMENTAL ASSETS}

In contrast to prevention science that focuses on negative developmental trajectories and outcomes, Positive Youth Development (PYD), a relatively new line of research and a developmental framework focuses on youth strengths and potentials for thriving in relation to developmental assets that are available in youth ecology (Benson, 2007; Bowers et al., 2011). However, both perspectives overlap to some extent, notably that youth development involves an interaction between the individual and his or her context. The understanding is that the individual is a product of this reciprocal relationship (Mueller et al., 2011), which for PYD, reflects an opportunity for adaptation and positive individual and ecological changes (Brandtstädter, 1998, 2006). PYD proposes that the individual-context interaction have implications for youth outcomes, such as academic achievement.

The interaction between the individuals and their context, and the effect this has on academic achievement can be explained by developmental system theories, 
such as Bronfenbrenner's ecological theory (Bronfenbrenner, 2005). Accordingly, academic achievement is a function of a student's dynamic interaction with several youth contexts in the micro-, meso-, exo- and macro-systems of Bronfenbrenner's ecological theory. Students are usually in contact with family, friends and school (in the micro-system) whose support could have significant consequences on their academic achievement. The meso-system reflects how collaboration between the home and school, for example, may have implications for academic achievement. The exosystem suggests how a condition in a distal context could influence students' academic achievement. For instance, educational resources made available to a given school can affect the school's capacity to facilitate learning and classroom activities, which in turn can influence students' academic performance. The macro-system is the cultural context that the individual is part of, and the social values in that culture. Accordingly, one could claim that libraries are an expression of a society's value of education and knowledge, and eventually, the value they place on academic performance. A fifth system, the chronosystem, accounts for how transition from a lower grade to a higher grade, for example can influence a student's academic performance. In the present study, we mainly focus on youth contexts in the micro- and meso-systems (i.e. home, school, peers and local community).

PYD suggests that there are different developmental assets in youth contexts, such as the home, school, neighbourhood and community. These contexts therefore represent key environments for positive youth development, with the possibility of an interaction that benefits both the youth and his or her context (Benson, 2007). Such adaptive regulations between youth and their context can lead to positive developmental paths. Academic achievement would be an important aspect of a positive developmental path.

Benson and colleagues proposed 40 developmental assets, which are resources defined as skills, opportunities, relationships and values that can promote thriving and resilience, but also decrease the likelihood of risk behaviours among youth (Benson, 2007; Benson et al., 2006). They proposed two categories of developmental assets: 20 internal and 20 external assets. Internal assets consist of four sub-categories: commitment to learning (i.e. understanding the importance of learning and believing in one's self abilities); positive values (i.e. developing values that can facilitate good life choices); social competence (i.e. ability to effectively interact with others, make choices and master new situations); and positive identity (i.e. believing in self-value and feeling of control over life). Similarly, external assets comprise four sub-categories: support (i.e. caring, appreciation and acceptance from persons in youth contexts); empowerment (i.e. context provides youth with a feeling of being valuable, safe and respected); boundaries and expectations (i.e. clear rules and consequences for behaviour in youth ecology, good role models, as well as encouragement and expectations of responsible behaviour); and constructive use of time (i.e. opportunity to interact with peers and adults in leisure activities and to learn new skills).

Internal and external assets are youth strengths and contextual resources that can be found in contexts that occupy, in particular, the micro- and meso-systems of Bronfenbrenner's ecological system. Developmental assets are thought to be additive, youth with high levels of assets also tend to have more positive development (e.g. greater academic achievement) relative to those who experience less assets (Scales et al., 2006a; 2006b). In a broader sense, experiencing higher levels of developmental assets will enable youth to thrive and become caring, responsible and productive adults who contribute to their society.

\section{DEVELOPMENTAL ASSETS AND ACADEMIC ACHIEVEMENT}

Scales et al. (2000) argued that youth who report a higher number of assets will, in comparison to youth who report lower numbers, have a greater likelihood of success in school. More importantly, academic achievement has been linked to several developmental assets including school engagement (reflecting commitment to learning, internal asset) and empowerment (external asset) (Scales et al., 2000). In a study involving 7000 American youth in 44 different states, Lerner and Lerner (2011) tested the hypothesis that positive youth development would occur if the strengths of youth were reinforced in contexts like family, school and the society. They found that youth with higher number of assets also reported higher academic competence and school engagement. Moreover, results from the same study indicated that school engagement, expressed both behaviourally and emotionally, was associated with lower risk of drug use and criminal behaviour (Lerner et al., 2011; Li, 2011). Thus, the promotion of school engagement could have both promotive and protective effects ( $\mathrm{Li}, 2011)$.

Scales and colleagues (2006a) conducted a longitudinal study where the role of developmental assets in academic success among 370 American students was examined. The students were followed over three years from $7^{\text {th }}-9^{\text {th }}$ grade through $10^{\text {th }}-12^{\text {th }}$ grade. The authors found a positive correlation between the number of developmental assets reported in $7^{\text {th }}-9^{\text {th }}$ grade and Grade Point Average (GPA) in both $7^{\text {th }}-9^{\text {th }}$ and $10^{\text {th }}$ $12^{\text {th }}$ grades. With the short- and long-term effects of developmental assets on GPA, Scales and colleagues' study supports PYD's assumption of plasticity, adaptive regulation and optimism in youth development (Scales et al., 2006a). The authors concluded that schools should have a broad focus on the 40 developmental assets when facilitating efforts that could contribute to academic success.

Furthermore, Upadyaya and Salmela-Aro (2013) completed a review of empirical research where they 
found that a high level of school engagement (reflecting an internal asset - commitment to learning) was associated with academic success. Like Lerner and colleagues (2011), Upadyaya and Salmela-Aro (2013) found that school engagement was negatively associated with poor mental health (i.e. depression symptoms), but positively associated with higher education, better job opportunities, life satisfaction, positive selfperception, and good health.

\section{THE PRESENT STUDY}

Research on developmental assets has mainly been done in the US context, although the number of studies involving non-US samples are increasing, for example in Albania, Bangladesh, Japan, Lebanon and the Philippines (Scales, 2011), Italy, Norway and Turkey (Wiium et al., 2018), Bulgaria and Kosovo (Wiium \& Uka, in press). In the present study, we assessed the link between developmental assets and academic achievement in a Norwegian high school context. Like previous studies, we examined whether there were gender differences in the report of the assets and the extent to which the different categories of assets were associated with academic achievement. In an article by Leffert and colleagues (1998), girls reported more developmental assets than boys, both in $6^{\text {th }}-8^{\text {th }}$ grade and in $9^{\text {th }}-12^{\text {th }}$ grade. Similar findings were observed by Scales and colleagues (2000).

Given that Norwegian high schools have high rates of dropouts, and that most of them are boys, together with earlier findings on the link between developmental assets and academic achievement, we expected girls to report more developmental assets than boys. Further, with the established relationship between the assets and positive outcomes in previous studies, we expected to find this positive link between the assets and academic achievement, also in our Norwegian sample. Concerning academic achievement, we examined both subjective and objective measures.

The aims of our study are relevant for several reasons. First, high school dropout has individual, economical and societal consequences, thus there is the need to nurture assets that will have positive implications for academic success. Second, if there is a connection between developmental assets and academic achievement, one could draw on the PYD perspective to strengthen schools' ability to facilitate good learning conditions. Third, if developmental assets are nurtured in the school context, all students, irrespective of their gender or socio-economic status will be reached in line with the Norwegian ideology of inclusive education (Fasting, 2013).

\section{METHOD}

\section{Participants}

Cross-sectional data were collected from 591 students attending a public high school in Bergen, as part of a cross-national research project. The age range was 15 19 years (mean age 16.70). 586 participants answered the question about gender, where 326 (55\%) were girls. Over half of the participants reported that their parents' highest education was college or university; about $56 \%$ reported having a father with post-secondary education, and $67 \%$ had a mother with similar level of education.

\section{Measures}

Developmental assets. Participants indicated the extent to which they had experienced Benson's (2007) 40 assets: the four internal asset categories (i.e., commitment to learning, positive values, social competencies and positive identity) and the four external asset categories (i.e., support, empowerment, boundaries and expectations and constructive use of time). Sample items for internal assets were "I am eager to do well in school", "I stay away from smoking, alcohol and drugs", "I am able to resolve conflicts without anyone getting hurt" and "I feel good about my future", respectively. For external assets, sample items were "I have support from adults other than my parents", "I am included in family tasks and decisions", "I have a school that provides clear rules and consequences" and "I am involved in creative things, such as music, theatre or other arts", respectively. Responses were rated on a 4-point Likert scale: (1) not at all or rarely, (2) somewhat or sometimes, (3) very or often, and (4) extremely or almost always.

In the present study, 51 items that reflect Benson's 40 assets were used. Cronbach's alpha for the eight sub-categories in internal and external assets ranged from .73 to .86 , except constructive use of time that had a Cronbach's alpha of .44. The Cronbach's alpha values found in this study reflect findings from earlier studies (e.g. Scales et al., 2000). As done in earlier studies, we considered all asset categories, including constructive use of time with the low alpha value in our data analyses and discussed the low Cronbach's alpha as a limitation in the discussion section.

Subjective academic achievement. Participants described their experience of own academic achievement: "How will you rank your academic achievement?". Response options ranged from 1-5: "Bad", "Satisfying", "Good", "Very good" and "Excellent".

Objective academic achievement. Participants were asked to report what grades they mostly achieve in school. Response options ranged from 1-8: "Mostly below 3s", "Mostly 3s", "About half $4 \mathrm{~s}$ and half 3s", "Mostly 4s", "About half 5s and half 4s", "Mostly 5s", "About half 6s and half 5s" and "Mostly 6s".

Demographics. Participants were asked to provide information about their age, gender (i.e. boy or girl) and educational level of their father and mother (i.e. no education, primary school, high school, technical or vocational school and university education). Age and educational level of father and mother were treated as control variables as they have been found to influence 
Table 1. Descriptive and correlation analysis of demographics, developmental assets and academic achievement.

\begin{tabular}{|c|c|c|c|c|c|c|c|c|c|c|c|c|c|}
\hline Study variables & 2 & 3 & 4 & 5 & 6 & 7 & 8 & 9 & 10 & 11 & 12 & 13 & 14 \\
\hline 1. $\operatorname{Age}^{\mathrm{a}}$ & .01 & $-.14^{* *}$ & $-.15^{* *}$ & $-.09^{*}$ & .03 & $-.15^{* *}$ & $-.11^{*}$ & -.08 & $-.11^{*}$ & -.03 & -.05 & -.07 & $-.17^{* *}$ \\
\hline 2. Gender & - & .00 & .00 & $.13^{* *}$ & .06 & $.14^{* *}$ & .02 & $.14^{* *}$ & $.16^{* *}$ & $.21^{* *}$ & $-.14^{* *}$ & .01 & .03 \\
\hline 3. Father's education & & - & $.35^{* *}$ & .03 & .06 & .03 & .00 & .04 & .03 & .06 & .06 & .05 & $.11^{*}$ \\
\hline 4. Mother's education & & & - & $.17^{* *}$ & .07 & $.12^{* *}$ & .06 & -.02 & -.01 & .02 & .05 & .07 & $.16^{* *}$ \\
\hline 5. Support & & & & - & $.57^{* *}$ & $.63^{* *}$ & $.30^{* *}$ & $.40^{* *}$ & $.31^{* *}$ & $.35^{* *}$ & $.36^{* *}$ & $.26^{* *}$ & $.22^{* *}$ \\
\hline 6. Empowerment & & & & & - & $.62^{* *}$ & $.31^{* *}$ & $.46^{* *}$ & $.34^{* *}$ & $.43^{* *}$ & $.51^{* *}$ & $.24^{* *}$ & $.23^{* *}$ \\
\hline 7. Boundaries and expectations & & & & & & - & $.30^{* *}$ & $.46^{* *}$ & $.41^{* *}$ & $.48^{* *}$ & $.39^{* *}$ & $.19^{* *}$ & $.18^{* *}$ \\
\hline 8. Constructive use of time & & & & & & & - & $.22^{* *}$ & $.18^{* *}$ & $.17^{* *}$ & $.23^{* *}$ & $.10^{*}$ & $.09^{*}$ \\
\hline 9. Commitment to learning & & & & & & & & - & $.54^{* *}$ & $.57^{* *}$ & $.43^{* *}$ & $.32^{* *}$ & $.34^{* *}$ \\
\hline 10. Positive values & & & & & & & & & - & $.65^{* *}$ & $.38^{* *}$ & $.12^{* *}$ & $.13^{* *}$ \\
\hline 11. Social competence & & & & & & & & & & - & $.47^{* *}$ & $.13^{* *}$ & $.15^{* *}$ \\
\hline 12. Positive identity & & & & & & & & & & & - & $.25^{* *}$ & $.22^{* *}$ \\
\hline 13. Subjective academic achievement & & & & & & & & & & & & - & $.53^{* *}$ \\
\hline 14. Objective academic achievement & & & & & & & & & & & & & - \\
\hline Descriptive analysis & $1-2$ & $1-5$ & $1-5$ & $0-7$ & $0-6$ & $0-9$ & $0-4$ & $0-7$ & $0-7$ & $0-7$ & $0-4$ & $1-5$ & $1-8$ \\
\hline Mean & 1.56 & 4.42 & 4.56 & 4.84 & 5.13 & 6.85 & 1.73 & 5.51 & 5.50 & 5.90 & 2.68 & 3.46 & 5.27 \\
\hline S.D. & 050 & 0.93 & 0.82 & 1.74 & 1.27 & 1.87 & 1.00 & 1.79 & 1.66 & 1.61 & 1.48 & 0.88 & 1.38 \\
\hline
\end{tabular}

${ }^{\mathrm{a}}$ Age range: $15-19 ;$ Mean $(\mathrm{SD})-16.70(.90) ; * * p<.01 ; * p<.05$.

the experience of developmental assets (Wiium et al., 2018).

\section{Procedure}

Data collection took place in 2015 with a response rate of $70 \%$. The school and participants gave informed consent prior to the data collection and after they had been informed about the goals and procedure of the study. Data collection lasted for about 40 minutes and was conducted during school hours. Students accessed the questionnaire over the school's internal web system. The study was approved by the Regional Committee for Medical and Health Research Ethics (REK) in Norway. Amesto Translation, a company specializing in interpretation services, translated the questionnaire from English to Norwegian.

\section{Data analysis}

Statistical analyses were done using IBM SPSS Statistics for Windows, version 24. Descriptive analysis was conducted on all study variables and correlation analysis was performed to investigate the direction and strength of the relationship between demographics, the asset categories and the two academic achievement variables. Further, a t-test was performed to investigate gender differences in the reports of the developmental asset categories. Finally, hierarchical regression analyses were conducted to explore the influence of the asset categories on academic achievement while controlling for the demographic variables. Hierarchical regression is a common analytical method that is used to examine the effect of a predictor variable (i.e. the asset categories) after controlling for other variables (i.e. the demographic variables). Consistent with Pedhazur (1997), hierarchical regression is an appropriate tool for analysis when variance in the outcome variable (i.e. academic achievement) is being explained by predictor variables that are correlated with each other, as is the case in the present study. One regression analysis was carried out for objective academic achievement and another for subjective academic achievement.

Composite variables that reflect the number of assets reported for each of the asset categories (four internal and four external) were created and used in the analyses. The original response alternatives were recoded, such that (1) "Never or rare" and (2) "Sometimes" was recoded as asset not present, and (3) "Often" and (4) "Almost always or Very often" recoded as asset present. Preliminary analyses were performed to determine the linearity and normal distribution of the data. Missing data were handled through "pairwise deletion", a procedure that excludes respondents from analysis when data is missing, and vice versa.

\section{ReSUlts}

\section{Descriptive and correlation analyses}

Participants reported more than $50 \%$ of the items that were used to measure each of the asset categories, in particular, empowerment and social competence. Their description of academic achievement was between "Good" and "Very good" for the subjective measure and "About half $5 \mathrm{~s}$ and half $4 \mathrm{~s}$ " for the objective measure (Table 1).

In correlation analysis, age correlated weakly and negatively with four of the asset categories: support, boundaries and expectations, commitment to learning and positive values with correlation coefficients ranging from - .09 to -.15 . Significant correlations were observed between gender and all the developmental assets except empowerment and constructive use of time, with five correlations (ranging from .13 to .21) in 
Table 2. Gender and developmental assets: A T-test analysis.

\begin{tabular}{|c|c|c|c|c|c|c|c|c|c|}
\hline \multirow[b]{3}{*}{ Developmental assets } & \multicolumn{6}{|c|}{ Gender } & \multirow[b]{3}{*}{$\mathrm{t}$} & \multirow[b]{3}{*}{ df } & \multirow[b]{3}{*}{ sig. } \\
\hline & \multicolumn{3}{|c|}{ Boys } & \multicolumn{3}{|c|}{ Girls } & & & \\
\hline & M & $\mathrm{SD}$ & $\mathrm{n}$ & $\mathrm{M}$ & $\mathrm{SD}$ & $\mathrm{n}$ & & & \\
\hline \multicolumn{10}{|l|}{ External assets } \\
\hline Support & 4.60 & 1.73 & 260 & 5.04 & 1.71 & 326 & -3.08 & 584 & .002 \\
\hline Empowerment & 5.05 & 1.35 & 260 & 5.20 & 1.18 & 326 & -1.43 & 584 & .154 \\
\hline Boundaries and expectations & 6.55 & 2.04 & 260 & 7.09 & 1.65 & 326 & -3.50 & 584 & .000 \\
\hline Constructive use of time & 1.72 & 1.05 & 260 & 1.75 & 0.95 & 326 & -0.35 & 584 & .724 \\
\hline \multicolumn{10}{|l|}{ Internal assets } \\
\hline Commitment to learning & 5.23 & 1.94 & 260 & 5.74 & 1.60 & 326 & -3.44 & 584 & .001 \\
\hline Positive values & 5.23 & 1.84 & 260 & 5.75 & 1.40 & 326 & -3.87 & 584 & .000 \\
\hline Social competence & 5.54 & 1.79 & 260 & 6.22 & 1.32 & 326 & -5.26 & 584 & .000 \\
\hline Positive identity & 2.90 & 1.39 & 260 & 2.50 & 1.51 & 326 & 3.33 & 584 & .001 \\
\hline
\end{tabular}

M - Mean; SD - Standard Deviation.

favour of girls (Table 1). No significant correlation was found with father's education while two positive but weak correlations with support $(r=.17, p<.01)$ and boundaries and expectations $(r=.12, p<.01)$ were found for mother's education. Weak to moderate correlations between objective academic achievement and age $(r=-.17, p<.01)$, father's education $(r=.16, p$ $<.01)$ and mother's education $(r=.22, p<.01)$ were found. Furthermore, significant correlations were observed between all the developmental assets and the two academic achievement variables, with correlations ranging from .09 to .34 (Table 1 ).

\section{Gender differences in developmental assets}

Based on findings in the correlation analysis, a t-test was conducted to investigate gender differences in the mean scores of the developmental assets. Results indicated that for external assets, girls reported more assets on support, $M=5.04, S D=1.71$ vs. $M=4.60, S D=$ $1.73, t=-3.08, d f=584, p=.002$, and boundaries and expectations $\mathrm{M}=7.09, \mathrm{SD}=1.65$ vs. $\mathrm{M}=6.55, \mathrm{SD}=$ $2.04, t=-3.50, d f=584, p=.000$, than boys.

For internal assets, girls reported higher mean scores on all four asset categories: commitment to learning, $M$ $=5.74, S D=1.60$ vs. $M=5.23, S D=1.94, t=-3.44$, $d f=584, p=.001$; positive values, $M=5.75, S D=$ 1.40 vs. $M=5.23, S D=1.84, t=-3.87, d f=584, p=$ .000 ; social competence, $M=6.22, S D=1.32$ vs. $M=$ 5.254, $S D=1.79, t=-5,26, d f=584, p=.000$; except positive identity, $M=2.50, S D=1.51$ vs. $M=2.90, S D$ $=1.39, t=3,33, d f=584, p=.001$, where boys reported a higher mean score (Table 2).

\section{Regression analysis of academic achievement}

In preliminary analyses, separate regression analyses for girls and boys gave relatively similar results; gender difference was only found for the association between empowerment and subjective academic achievement, where the asset category was significantly associated with the outcome variable for girls, but not for boys. Fisher z-test indicated that this gender difference was significant $(p=.03)$. However, although girls were more likely to report most of the asset categories as indicated by results from the correlation and t-test analyses, for both boys and girls, the associations between the asset categories (except empowerment) and the academic achievement variables were similar in strength. Based on the findings indicating minimal gender differences in the strength of the associations, a decision was made to conduct one regression analysis for both genders.

Subjective academic achievement as dependent variable. Variables in step 1 (age, gender, father's and mother's education) explained about $1 \%$ of the variance in subjective academic achievement $\left(R^{2}=.009\right)$. In step 2, when the developmental asset categories were added to the model, the explained variance increased to $15 \%\left(R^{2}=.150\right)$. Thus, the developmental assets explained about $14 \%$ of the variance in subjective academic achievement. Three variables, all developmental assets, were significantly associated with subjective academic achievement; commitment to learning $(\beta=$ $.301, p=.000)$, support $(\beta=.135, p=.024)$ and positive identity $(\beta=.133, p=.018)$ (Table 3$)$.

Objective academic achievement as dependent variable. Demographic variables in step 1 (age, gender, father's and mother's education) explained about 5\% $\left(R^{2}=.049\right)$ of the variance in objective academic achievement. When the developmental assets were included in step 2, the explained variance increased to $18 \%\left(R^{2}=.183\right)$, indicating that the developmental assets explained about $13 \%$ of the variance in objective academic achievement. Three variables were significantly related to objective academic achievement, but only one of them was a developmental asset: commitment to learning $(\beta=.346, p=.000)$. The other two were age $(\beta=-.138, p=.002)$ and mother's education $(\beta=.123, p=.009)$ (Table 3$)$.

\section{Discussion}

\section{General findings}

Based on the theoretical framework of Positive Youth Development, the present study investigated 1) gender differences in the report of the developmental assets, 
Table 3. Regression analyses of developmental assets and academic achievement.

\begin{tabular}{|c|c|c|c|c|c|c|c|c|}
\hline & \multicolumn{4}{|c|}{ Subjective academic achievement } & \multicolumn{4}{|c|}{ Objective academic achievement } \\
\hline & \multicolumn{2}{|c|}{ Unstandardized coefficient } & \multirow[b]{2}{*}{$\beta$} & \multirow[b]{2}{*}{ Sig. } & \multicolumn{2}{|c|}{ Unstandardized coefficient } & \multirow[b]{2}{*}{$\beta$} & \multirow[b]{2}{*}{ Sig. } \\
\hline & $\mathrm{B}$ & S.E. & & & $\mathrm{B}$ & S.E. & & \\
\hline \multicolumn{9}{|l|}{ Step 1} \\
\hline Age & -.057 & .046 & -.058 & .223 & -.221 & .071 & -.145 & .002 \\
\hline Gender & .012 & .082 & .007 & .880 & .090 & .126 & .032 & .477 \\
\hline Father's education & .025 & .047 & .026 & .597 & .066 & .072 & .044 & .363 \\
\hline Mother's education & .055 & .054 & .051 & .305 & .201 & .082 & .119 & .015 \\
\hline \multicolumn{9}{|l|}{ Step 2} \\
\hline Age & -.037 & .045 & -.038 & .407 & -.211 & .069 & -.138 & .002 \\
\hline Gender & .004 & .083 & .002 & .960 & .061 & .127 & .022 & .632 \\
\hline Father's education & .017 & .044 & .018 & .702 & .041 & .068 & .028 & .546 \\
\hline Mother's education & .040 & .052 & .037 & .440 & .208 & .079 & .123 & .009 \\
\hline Support & .069 & .030 & .135 & .024 & .056 & .046 & .071 & .230 \\
\hline Empowerment & .036 & .044 & .052 & .414 & .112 & .067 & .104 & .095 \\
\hline Boundaries and expectations & -.020 & .031 & -.042 & .519 & -.067 & .047 & -.091 & .153 \\
\hline Constructive use of time & -.014 & .042 & -.016 & .739 & -.047 & .063 & -.034 & .457 \\
\hline Commitment to learning & .149 & .029 & .301 & .000 & .266 & .044 & .346 & .000 \\
\hline Positive values & -.035 & .032 & -.035 & .276 & -.054 & .048 & -.065 & .269 \\
\hline Social competence & -.060 & .036 & -.110 & .092 & -.070 & .055 & -.082 & .198 \\
\hline Positive identity & .080 & .034 & .133 & .018 & .082 & .051 & .088 & .110 \\
\hline
\end{tabular}

S.E. - Standard Error

and 2) whether the established relation between developmental assets and academic achievement in US youth samples can also be found in a Norwegian youth sample. The results indicated that there were gender differences in the report of developmental assets in our Norwegian sample. More specifically, girls reported more assets on support, boundaries and expectations, commitment to learning, positive values and social competence, relative to boys, while boys reported more assets on positive identity, relative to girls.

Although girls reported more assets than boys, preliminary findings indicated that the associations between the assets and academic achievement were quite similar in strength for both genders. Hence, in the regression analyses, data from the two genders were analysed together as one sample. Correlation and regression analyses suggested that the developmental asset categories were related to the academic achievement factors, although in regression analysis only three developmental asset categories remained significantly associated to the factors. In particular, commitment to learning was significantly associated with both the subjective and objective measure of academic achievement, while support and positive identity were each related to subjective academic achievement.

\section{Gender and developmental assets}

The present findings on gender differences in the report of the developmental assets are consistent with earlier studies in the US (e.g. Leffert et al., 1998). The gender differences could stem from sociocultural gender norms, and the social political focus in Norway (e.g. gender equality). Nevertheless, in our preliminary analysis, developmental assets had similar significance for academic achievement in both genders. Earlier research shows a link between school dropout and academic achievement. School can therefore play a significant role in nurturing developmental assets that will promote academic success in both genders that may have implications for dropout rates and consequently, societal and economic development. Statistics from the Norwegian Directorate for Education and Training (2017) suggest that girls obtain higher grades than boys in high school. Given the early finding that most high school dropouts are boys (Norwegian Directorate for Children, Youth and Family Affairs, 2017), and the current finding that they report fewer assets than girls, one could question whether the school system in Norway, as an important aspect of youth ecology, is adequately targeting the developmental needs of boys.

Lillejord and colleagues (2017) reported that girls and boys experience challenges in academic achievement differently. They found that girls more frequently report pressure in requirements and achievement, while boys more often distance themselves from school. An imbalance in requirements and expectations to academic achievement in youth ecology could have negative consequences on high school students. However, aspects of positive youth development and a focus on promoting developmental assets, where the aim is not only to enhance academic achievement but also thriving and well-being in general, could be one solution to students' challenges and the increased dropout rates in high schools.

\section{Developmental assets and academic achievement}

Despite the moderate to strong correlation found between the subjective and objective measures of academic achievement, more developmental asset categories appeared to be related to the subjective measure compared to the objective measure. While students' academic grades may not sufficiently capture the subjective assessment of their academic performance, 
the significance of developmental assets on academic achievement is again confirmed, this time, in a Norwegian context, although in the present study, it was only commitment to learning, support and positive identity that maintained their significance in the regression analyses. Nevertheless, in correlation analysis, there was an indication that all the asset categories were associated with the academic achievement factors, given their statistically significant correlations.

Longitudinal research involving US samples found that high prevalence of developmental assets reflected higher grades in both short- and long-term (Scales et al., 2006a), and that developmental assets predicted academic achievement 2-4 times better than demographic variables (Roehlkepartain et al., 2003; Benson, 2007). The present study was not a longitudinal study, nevertheless, we found similar results, where developmental assets, especially commitment to learning, support and positive identity appeared to be strongly related to academic achievement better than the demographic factors that were studied. Besides, several studies support the assumption that the promotion of developmental assets could have positive consequences for academic achievement (Scales et al., 2006a; Starkman et al., 1999).

As part of youth ecology, schools have a unique position to interact with youth and are thus, of great importance for positive development. Students who experience challenges in other youth contexts could still be well equipped for positive development, with the compensating effect that schools could have. Moreover, the promotion of developmental assets has been shown to contribute to reducing the gap between students from low and high socioeconomic background (Scales et al., 2006b). Thus, the stimulation of developmental assets can especially be important for students who perceive that the requirements and expectations from high school exceed their personal resources, which could eventually make them victims of prolonged negative stress (Lillejord et al., 2017). This imbalance in the stress related to expectations, on one hand and resources, on the other, could be a possible reason for mental health issues and high school dropout rates.

The perceived imbalance between expectations and resources has received much attention lately in Norway, with emphasis on how academic success and grades come at the expense of students' quality of life. Nurturing developmental assets in the school context could be a solution, where supportive school environments are created to meet the needs of students, irrespective of their gender, age or socio-economic background (Scales \& Taccogna, 2000). Benson (2007) argued that young people have the potential to increase their developmental assets, if the assets are facilitated in their contexts. Accordingly, such intentional facilitation of health promoting resources can help students interact in a more adaptive way with their context.

\section{Limitations}

Despite the positive findings, there are some limitations related to the present study. First, all participants were students at the same school. This limits the results in terms of a general representation of developmental assets and academic achievement in the Norwegian context. Ideally, one would prefer a selection that included schools from different cities in Norway. However, it is worth mentioning that despite the study's shortcomings, the present results reflect earlier findings from diverse samples and designs (Scales et al., 2000, 2006a).

Second, the questionnaire was developed for the US context. As such developmental assets unique to the Norwegian context may not be adequately captured. For example, some of the items in constructive use of time (i.e., "I am involved in a church, mosque, or other religious group one or more hours every week") may not relate as much to Norwegian youth, as indicated by the low proportion of the asset reported by both genders and the low Cronbach's alpha that was estimated. Besides, as mentioned earlier, not all the asset categories were strong predictors of academic achievement when they were examined simultaneously. Future studies can use mixed-method approaches to study assets that sufficiently capture youth resources compatible with the Norwegian context. In addition, longitudinal design can also be utilized to confirm the link between assets and academic achievement in this non-US context.

Third, measures of academic achievement were based on self-report. This could imply some form of bias related to social desirability. Students selfreported their objective measure of academic achievement. This could differ from teachers' or schools' report of the measure, which we encourage to use in future studies.

\section{Implications for research, policy and practice}

Despite the limitations, the present findings suggest that developmental assets that were developed in the US contexts were also reported to some extent among Norwegian youth. A closer look at findings observed in US samples reveal that a greater number of the asset categories are related to academic achievement compared to what was found in the present study. This difference could be due to the sociocultural differences between the two countries. For example, with the issue of religious participation in the constructive use of time asset category, Norway tends to be more secularized than the US, making the asset more relevant to American youth than Norwegian youth. Thus, for Norway, future research on developmental assets and its implication for youth development can build on the current findings by including larger and more representative samples, as well as qualitative and quantitative measures that will uncover the relevant developmental 
assets needed to enhance thriving and well-being among Norwegian youth.

With the established association between assets and academic achievement in earlier studies, and the finding that this association is also true for Norwegian youth, policies at the local, regional and national level can be formulated and implemented in youth contexts, such as the home, school and local community. This will ensure that assets are available in the context in which youth participate and that all youth can equally access the personal and contextual resources they need to develop their full potential. A policy that regulates the promotion of assets at school for example, could contribute to reducing gender differences in the report of developmental assets and eventually promote not only academic achievement but also general wellbeing among students as more attention will be given to the structure and process that regulate and facilitate the assets in the school context.

There are several practical implications of the present findings as well. Based on the positive findings, strategies and initiatives can be developed to use at home, school and other youth contexts to enable youth increase their assets. Developmental assets can be strengthened if youth's level of experience of them is low. This applies to all youth, regardless of their gender, age and socio-economic background. Youth who perceive that they possess the necessary personal and contextual assets do not only thrive but they also are less likely to engage in risk behaviours, such as alcohol- and drug use and crime.

Principles of Positive Youth Development could have a practical function as a framework for contexts, such as schools and recreational activities, where youth interact with each other and adults. Developmental assets are not only found in the school context, but also at home, peer context and local community. However, schools have a unique position to work with the local community in terms of recreational activities, peers and with the family to nurture assets in different contexts. Schools could host activities or otherwise convey different ways that the family, peers and local community as well as youth themselves could become supporters of youth in the growth and sustenance of developmental assets.

\section{CONCLUSION}

This paper investigated gender differences in the report of developmental assets among high school students in Norway and the association that may exist between their developmental assets and academic achievement. Findings suggest several gender differences in the report of the developmental assets (in favour of girls) and significant associations between the developmental assets and academic achievement. However, more research on developmental assets in the Norwegian context is needed, as aspects that are unique to the Norwegian context need to be assessed and advanced.

The school is an arena where youth spend a lot of time, and is also involved in different relationships (with parents, teachers, peers and the society) that are essential to youth development. Schools could therefore be an important stakeholder that teams up with other stakeholders of youth development to ensure that youth have access to the developmental assets needed for their development. School success is of great value for both individual and society. With school success, the likelihood of negative developmental paths, and the eventual economic consequences for both individual and society are reduced. Positive youth development and a focus on promoting developmental assets could contribute to an increased probability of youth finishing high school, and growing up to become responsible adults that make positive contributions not only to themselves but also to the society they are part of.

\section{REFERENCES}

Benson, P. L. (2007). Developmental assets: An overview of theory, research, and practice. In R. Silbereisen, \& R. Lerner (Eds.), Approaches to positive youth development (pp. 33-59). London: Sage Publications.

Benson, P. L., Scales, P. C., Hamilton, S. F., \& Sesma Jr., A. (2006). Positive youth development: Theory, research, and applications. In R. M. Lerner, \& W. Damon, (Eds.), Handbook of child psychology (6th ed.). Vol. 1, Theoretical models of human development (pp. 894-941). Hoboken, NJ: John Wiley \& Sons.

Bowers, E. P., von Eye, A., Lerner, J. V., Arbeit, M. R., Weiner, M. B., Chase, P., \& Agans, J. P. (2011). The role of ecological assets in positive and problematic developmental trajectiories. J Adolesc 34, 1151-1165.

Brandtstädter, J. (1998). Action perspectives on human development. In W. Damon, \& R. M. Lerner (Eds.), Theoretical models of human development. Handbook of child Psychology (Vol. 1, 5th ed., pp. 807-863). New York: Wiley.

Brandtstädter, J. (2006). Action perspectives on human development. In W. Damon, \& R. M. Lerner (Eds.), Theoretical models of human development. Handbook of child Psychology (Vol. 1, 6th ed., pp. 516-568). Hoboken, NJ: Wiley.

Bronfenbrenner, U. (Ed.). (2005). Making human beings human: Bioecological perspectives on human development. Thousand Oaks, CA: Sage Publications.

Fasting, R. B. (2013). Adapted education: The Norwegian pathway to inclusive and efficient education. Int $J$ Inclusive Educ 17(3), 263-276. 
Gender Equality (2017). The Norwegian Government. Retrieved from: https://www.regjeringen.no/globalassets/upload/bld/action_plan_2014.pdf

Leffert, N., Benson, P. L., Scales, P. C., Anu R., Sharma, A. R., Drake, D. R., \& Blyth, D. A. (1998). Developmental assets: Measurement and prediction of risk behaviors among adolescents. Appl Dev Sci 2(4), 209-230.

Lerner, R. M. (2005). Foreword. Urie Bronfenbrenner: Career contributions of the consummate developmental scientist. In U. Bronfenbrenner, Making human beings human (pp. ix-xxvi). Thousand Oaks, CA: Sage Publications.

Lerner, R. M., Brentano, C., Dowling, E. M., \& Anderson, P. M. (2002). Positive youth development: Thriving as the basis of personhood and civil society. New Directions for Youth Development 95, 11-33.

Lerner, R. M., \& Lerner, J. V. (2011). The positive development of youth. Report of the findings from the first seven years of the 4-H Study of Positive Youth Development. Institute for Applied Research in Youth Development, Tufts University.

Lerner, R. M., Lerner, J. V., von Eye, A., Bowers, E. P., \& Lewin-Bizan, S. (2011). Individual and contextual bases of thriving in adolescence: A view of the issues. J Adolesc 34, 1107-1114.

Levin, H. M., \& Belfield, C. R. (2007). Educational interventions to raise high school graduation rates. In C. R. Belfield \& H. M. Levin (Eds.), The price we pay for: Economic and social consequences of inadequate education (pp. 177-199). Washington, DC: Brookings Institution Press.

Li, Y. (2011). School engagement: What it is and why it is important for positive youth development. In R. M. Lerner, J. V. Lerner, \& J. B. Benson (Eds.), Advances in child development and behavior (Vol. 41, pp. 131160). Netherlands: Elsevier JAI.

Lillejord S., Børte K., Ruud E., \& Morgan, K. (2017). Stress i skolen - en systematisk kunnskapsoversikt. Oslo: Kunnskapssenter for utdanning.

Mueller, M. K., Phelps, E., Bowers, E. P., Agans, J. P., Urban, J. B., \& Lerner, R. M. (2011). Youth development program participation and intentional self-regulation skills: Contextual and individual bases of pathways to positive youth development. J Adolesc 34, 1115-1125.

Pedhazur, E. J. (1997). Multiple regression in behavioral research (3rd ed.). Orlando, FL: Harcourt Brace.

Roehlkepartain, E. C., Benson, P. L., \& Sesma, A. (2003). Signs of progress in putting children first: Developmental assets among youth in St. Louis Park, 1997-2001. Minneapolis, MN: Unpublished report prepared by Search Institute for St. Louis Park's Children First Initiative.

Scales, P. C. (2011). Youth developmental assets in global perspective: Results from international adaptations of the Developmental Assets Profile. Child Indic Res 4, 619-645.

Scales, P. C., Benson, P. L., Leffert, N., \& Blyth, D. A. (2000). Contribution of developmental assets to the prediction of thriving among adolescents. Appl Dev Sci 4, 1, 27-46.

Scales, P. C., Benson, P. L., Roehlkepartain, E. C., Sesma Jr., A., \& van Dulmen, M. (2006a). The role of developmental assets in predicting academic achievement: A longitudinal Study. J Adolesc 29, 691-708.

Scales, P. C., Roehlkepartain, E. C., Neal, M., Kielsmeier, J. C., \& Benson, P. L. (2006b). Reducing academic achievement gaps: The role of community service and service-learning. J Exp Educ 29(1), 38-60.

Scales, P. C., \& Taccogna, J. (2000). Caring to try: How building students' developmental assets can promote school engagement and success. NASSP Bulletin 84(619), 69-78.

Starkman, N., P. C. Scales \& C. Roberts. 1999. Great places to learn: How asset-building schools help students succeed. Minneapolis: Search Institute.

Statistics Norway (2017). Gjennomføring i videregående opplæring. Retrieved from https://www.ssb.no/vgogjen.

Upadyaya, K., \& Salmela-Aro, K. (2013). Development of school engagement in association with academic success and well-being in varying social contexts: A review of empirical research. Eur Psychol 18(2), 136-147.

The Norwegian Directorate for Children, Youth and Family Affairs (2017). Gjennomføring og frafall i skolen. Retrieved from: https://www.bufdir.no/Statistikk_og_analyse/Oppvekst/Barnehage_og_skole/Gjennomforing og_frafall_i_skolen/.

The Norwegian Directorate for Education and Training (2017). Karakterer i videregående opplæring. Retrieved from https:/www.udir.no/tall-og-forskning/finn-forskning/tema/karakterer/karakterer-i-videregaende/.

Union of education (2017). Frafall i videregående opplæring. Retrieved from https:/www.utdanningsforbundet.no/var-politikk/utdanningsforbundet-mener/artikler/frafall/.

Wiium, N., Dost-Gözkan, A. \& Kosic, M. (2018). Developmental assets among young people in three European contexts: Italy, Norway and Turkey. Child \& Youth Care Forum. https://doi.org/10.1007/s10566-018-9446-1.

Wiium, N., \& Uka, F. (in press). Positive youth development: An empirical study of Roma youth. In Dimitrova, R., Sam, D., \& Ferrer-Wreder, L. (Eds.) Roma minority youth across cultural contexts: Taking a positive approach to research, policy and practice. Oxford University Press. 